\title{
Understanding the Concept of Integrity among Malaysian Immigration Department Staff State of Kedah
}

\author{
Anuar Puteh* \\ Nor Akrimi Mohd Ali \\ Abdul Ghafar Don \\ Zulkefli Aini $^{1}$
}

\begin{abstract}
Integrity is absolutely necessary to produce a society that is professionally advanced and based on noble character. This study is based on issues and problems of integrity that often associated with civil servants in Malaysia. The aim of the study is, therefore to examine the understanding of Kedah Immigration Department staff on the concept of integrity. The findings of the study show that the level of understanding of Kedah Immigration Department staff on the concept of integrity records a mean score $(m=4.23, s p=.410)$. The findings revealed that immigration officers have a high level of understanding on the concept of integrity. Based on the results of the study, various efforts should be undertaken by all segments of the society, educational institutions, religious institutions and the government to ensure that personal values and values in employment continue to be instilled among civil servants in Malaysia to achieve the objective of integrity.
\end{abstract}

Keywords: Understanding, Integrity Values, Malaysian Immigration Department

This study discusses an important aspect of human life, which is integrity. Integrity is important in life because it is a guarantee of professional human development, while at the same time being supported by moral and ethical standards that will directly contribute to community well-being and organizational excellence. Integrated societies and organizations contribute to the development and civilization of a nation. Integrity is therefore an identity that is essential for every individual.

Integrity in the Webster's collegiate Dictionary of Cannibalism (1996) is expressed as adherence to a code of ethics or a rule especially a code of moral ethics. The term integrity is used to describe a strong and stable state (Carter 1996), and to describe the state of high moral individualism (Bauman 2013). The question of integrity is emphasized in Islam in particular through the concept of trust (Al-Qur'an, Surah al-Nisa '4:58). Recognizing the importance of integrity as one of the mediums for developing human capital, the Malaysian government took the initiative to cultivate integrity in Malaysian society through the establishment of the National Integrity Plan (PIN) and the Malaysian Institute of Integrity on April 23, 2004.

The main purpose of integrity introduced in Malaysia is to create a society that has strong moral and ethical characteristics, has high religious and spiritual concepts, and is endowed with high personalities (PIN 2004). Strengthening the integrity of Malaysia is an important endeavor for the country because of the diversity of people of many races and religions in Malaysia. Religious and customary differences require the conceptual clarity in order to unify the identity of Malaysians. Thus, integrity is strengthened to promote the identity of Malaysians through the appreciation of pure concepts.

\footnotetext{
${ }^{1}$ Anuar Puteh* (corresponding author), MA., senior lecturer at Research Centre for Dakwah and Leadership, Faculty of Islamic Studies, Universiti Kebangsaan Malaysia, 43600 BANGI, Selangor, Malaysia, email: anteh@ukm.edu.my; Nor Akrimi Mohd Ali, MA., teacher at SRA Sungai Tangkas, 43600 BANGI, Selangor, email:kiemy_180191@yahoo.com; Abdul Ghafar Don, Ph.D., Assoc. Professor at Research Centre for Dakwah and Leadership, Faculty of Islamic Studies, Universiti Kebangsaan Malaysia, 43600 BANGI, Selangor, Malaysia, email: a.g.don@ukm.edu.my. Zulkefli Aini, Ph.D., senior lecturer at Research Centre for Dakwah and Leadership, Faculty of Islamic Studies, Universiti Kebangsaan Malaysia, 43600 BANGI, Selangor, Malaysia,
} 
Lately, many cases of misconduct have involved civil servants. Statistics from the Malaysian Anti-Corruption Commission (MACC) show that during 2012-2014, many civil servants were prosecuted for misconduct and a total of 688 complaints received by the MACC were taken by government agencies (Azura Sahril 2015). The start of 2016 was also alarmed by the arrest of a civil servant by the Secretary of Youth and Sports Division who faced 32 charges of corruption involving a very high concept of RM 38.4 million (Maisarah 2016). As well as the increasing public complaints received by the Public Complaints Bureau which has made complaints about misconduct cases and so on.

Civil servants are individuals responsible for the governance of public institutions in Malaysia. Therefore, they must have high integrity because they are individuals who exercise trust and authority in the best interest of the public. According to the National Integrity Plan (PIN 2004), integrity-conscious civil servants should be able to do their job without abusing the power of their own interests, family, relatives or relatives. Even uneducated workers will become traitors to the organization.

This study focused on the aspect of integrity among the staff of one of the public service agencies in Malaysia namely the Malaysian Immigration Department, especially the Kedah Malaysia Immigration Department. The Immigration Department was chosen because it is a very important agency to the country. The department is a government agency under the Ministry of Home Affairs (KDN) responsible for managing immigration matters.

\section{Method of Study}

This study is a quantitative study using survey design design. Through this study, the subject of this study focused on assessing the understanding of the sample of the study staff of Kedah Malaysia Immigration Department staff on the question of concept of integrity. In the event of misconduct and mismanagement in this aspect of immigration, it will have a devastating effect on the country. In order to compensate for or overcome problems of misconduct and deviations from this aspect of immigration affairs, it is emphasized that the internal aspects of its staff should be taken into account such as aspects of integrity.

The Immigration Department was chosen because it is one of the backbones of the country's security and sovereignty especially with regard to affairs at the national border. Meanwhile, the Kedah State Immigration Department was chosen specifically because it is located near the state border for the northern zone.

This study uses questionnaire instruments. The use of questionnaires in data collection allowed more respondents to be surveyed in a more comprehensive and comprehensive way (Munawar \& Nor Shahizan 2012). Questionnaire is one of the most frequently used instruments in descriptive research with survey design because through this method cooperation from respondents is easily obtained. Questionnaires are commonly used to obtain information on facts, beliefs, feelings, desires and so on (Noraini 2010). The use of a questionnaire also allows the researcher to use a large number of respondents at a time and this saves time and expense for a study being conducted.

A set of questionnaires was developed to obtain information on respondents' understanding of the concept of integrity. The questionnaire on understanding of the concept of integrity involves three constructs namely, understanding of terms, understanding of goals / interests and understanding of the implementation of integrity developed by researchers based on reader reviews of past works and studies. These items were developed by the researcher and not adapted from previous studies except for some items in the constructive understanding of terms of integrity adapted from the study of Hanafi Hamdani (2014). The questionnaire that was developed was then referred to the field specialist for review and verification.

The researcher obtained permission from the Kedah State Immigration Department to conduct the study. Prior to distributing the questionnaire, the researcher began the process of obtaining the total population of the study area. Next, we performed the sampling process to determine the appropriate sample size to represent the entire population of 175 people.

Out of the 175 people, the study recruited only 167 people comprising Muslim staff on the grounds that the questionnaire was not suitable for non-Muslims.

The questionnaire was distributed to the staff of the Immigration Department of Malaysia, Kedah by hand. Each questionnaire is accompanied by a description and purpose of the questionnaire. The researcher managed to reassemble 162 questionnaires and 5 questionnaires had to be discarded due to an unavoidable error making only 157 questionnaires suitable for analysis.

To derive the reliability of the items in this questionnaire, Cronbach's alpha coefficient by Kirk (1984) was used. 
Table 1 Classification of reliability index

\begin{tabular}{ll}
\hline Indicators & Alpha Cronbach's \\
\hline Very high & $>0.90$ \\
High & $0.70-0.89$ \\
Medium & $0.30-0.69$ \\
Low & $<0.30$ \\
\hline
\end{tabular}

Source: Kirk (1984)

This study uses a descriptive analysis approach. Descriptive techniques are intended to describe the data obtained from the questionnaire and are described in tables and diagrams with descriptions in terms of frequency, percentage, average (mean) and standard deviation. According to Azizi (2007), descriptive statistics contain charts, graphs and tables. Through descriptive statistics the findings or conclusions of the study can be conveyed in a form easily understood by the target group. All data encoded in the questionnaire obtained from the respondents were entered into the computer for analysis using Statistical Package for Social Science (SPSS) version 22.0. The use of this program enables quantitative data to be analyzed quickly and easily and facilitates the study (Bryman \& Cramer 2005).

\section{Research Findings (Kedah Respondents' Understanding of the Terms of Integrity)}

Failure to properly understand the concept of integrity can result in the loss of integrity (Carter 1996). Thus the understanding of integrity in this study is measured by understanding the concept of integrity alone. Descriptive analysis of this section was conducted to obtain frequency distributions, percentages, mean scores and standard deviations of respondents' level of understanding of terms of integrity.

In order to build an understanding of the term integrity, the researcher has submitted 8 items with the KI1 label KI8. Items KI1 and KI2 are more focused on meaning and robustness. Whereas items KI3 and KI8 are terms of integrity that convey meaning and value in life. Item KI4 is about consistency in doing good, while item KI5 is about alignment between actions and words. Items KI6 and KI7 are related to one's perfection and aspects of self-development to perfection (integrity). All of the items presented are based on the review and references of previous works and studies such as PIN (2004), Carter (1996), Palanski \& Yammarino (2007 \& 2009), Jamiah Manap et al. (2005) and Hanafi Hamdani (2014). Frequency analysis, percentage, mean score and standard deviation are shown in table 2 below. 
Table 2 Frequency distribution, percentage, mean and standard deviation of respondents' understanding of terms of integrity

\begin{tabular}{|c|c|c|c|c|c|c|c|c|c|}
\hline Bil. & Item & $\begin{array}{l}\text { STS } \\
(\%)\end{array}$ & $\begin{array}{l}\text { TS } \\
(\%)\end{array}$ & $\begin{array}{l}\text { TP } \\
(\%)\end{array}$ & $\begin{array}{l}\mathbf{S} \\
(\%)\end{array}$ & $\begin{array}{l}\text { SS } \\
(\%)\end{array}$ & Min & SP & INT \\
\hline KI1 & $\begin{array}{l}\text { Integrity is } \\
\text { perfect, solid and } \\
\text { strong }\end{array}$ & - & $\begin{array}{l}1 \\
0.6 \%\end{array}$ & $\begin{array}{l}6 \\
3.8 \%\end{array}$ & $\begin{array}{l}99 \\
63.1 \%\end{array}$ & $\begin{array}{l}51 \\
32.5 \%\end{array}$ & 4.27 & .562 & high \\
\hline KI2 & $\begin{array}{l}\text { Integrity means } \\
\text { personal integrity }\end{array}$ & $\begin{array}{l}1 \\
0.6 \%\end{array}$ & - & $\begin{array}{l}2 \\
1.3 \%\end{array}$ & $\begin{array}{l}103 \\
65.6 \%\end{array}$ & $\begin{array}{l}51 \\
32.5 \%\end{array}$ & 4.29 & .558 & high \\
\hline $\mathrm{KI} 3$ & $\begin{array}{l}\text { Integrity is a } \\
\text { combination of } \\
\text { positive values } \\
\text { and noble } \\
\text { practices in life }\end{array}$ & - & - & $\begin{array}{l}8 \\
5.1 \%\end{array}$ & $\begin{array}{l}89 \\
56.7 \%\end{array}$ & $\begin{array}{l}60 \\
38.2 \%\end{array}$ & 4.33 & .570 & high \\
\hline KI4 & $\begin{array}{l}\text { Integrity is } \\
\text { consistent in all } \\
\text { good deeds }\end{array}$ & - & $\begin{array}{l}1 \\
0.6 \%\end{array}$ & $\begin{array}{l}13 \\
8.3 \%\end{array}$ & $\begin{array}{l}86 \\
54.8 \%\end{array}$ & $\begin{array}{l}57 \\
36.3 \%\end{array}$ & 4.27 & .634 & high \\
\hline KI5 & $\begin{array}{l}\text { Integrity is the } \\
\text { harmony } \\
\text { between } \\
\text { individual } \\
\text { conversations } \\
\text { and actions }\end{array}$ & $\begin{array}{l}1 \\
0.6 \%\end{array}$ & $\begin{array}{l}2 \\
1.3 \%\end{array}$ & $\begin{array}{l}15 \\
9.6 \%\end{array}$ & $\begin{array}{l}91 \\
58.0 \%\end{array}$ & $\begin{array}{l}48 \\
30.6 \%\end{array}$ & 4.16 & .696 & high \\
\hline KI6 & $\begin{array}{l}\text { An individual } \\
\text { with integrity is a } \\
\text { person of perfect } \\
\text { behavior }\end{array}$ & $\begin{array}{l}1 \\
0.6 \%\end{array}$ & $\begin{array}{l}5 \\
3.2 \%\end{array}$ & $\begin{array}{l}21 \\
13.4 \\
\%\end{array}$ & $\begin{array}{l}82 \\
52.2 \%\end{array}$ & $\begin{array}{l}48 \\
30.6 \%\end{array}$ & 4.09 & .787 & high \\
\hline KI7 & $\begin{array}{l}\text { Integrity is the } \\
\text { refinement and } \\
\text { improvement of } \\
\text { each task for } \\
\text { perfection }\end{array}$ & - & $\begin{array}{l}3 \\
1.9 \%\end{array}$ & $\begin{array}{l}14 \\
8.9 \%\end{array}$ & $\begin{array}{l}88 \\
56.1 \%\end{array}$ & $\begin{array}{l}52 \\
33.1 \%\end{array}$ & 4.20 & .676 & high \\
\hline KI8 & $\begin{array}{l}\text { Integrity is a } \\
\text { moral value that } \\
\text { is consistent with } \\
\text { the teachings of } \\
\text { each religion }\end{array}$ & - & $\begin{array}{l}4 \\
2.5 \%\end{array}$ & $\begin{array}{l}13 \\
8.3 \%\end{array}$ & $\begin{array}{l}77 \\
49.0 \%\end{array}$ & $\begin{array}{l}63 \\
40.1 \%\end{array}$ & 4.27 & .719 & high \\
\hline & Jumlah & & & & & & 4.23 & .410 & high \\
\hline
\end{tabular}

Source : questionnaire 2017

\section{Discussion of Findings}

Overall the respondents' understanding of the term integrity was high (mean score $=4.23, \mathrm{Sp}=.410$ ). The highest mean scores were on items KI3 (integrity is a combination of positive values and good practices in life), followed by items KI2 (integrity means personal integrity), KI4 (integrity is consistent with all good deeds and deeds),

KI8 (integrity are pure values that are in line with the teachings of each religion), KI1 (integrity is perfect, intact and strong), KI7 (integrity is to repair and advance each task), KI5 (integrity is the harmony between conversation and action) and lastly KI6 (individuals with integrity are the perfect people).

All the mean scores for the items in this construct recorded a high value of between 4.09 and 4.33.

It is therefore understandable that the term integrity introduced in Malaysia and used by past studies is well understood by the respondents. The respondents' understanding of the term integrity is in line with the introduction and emphasis on integrity in Malaysia. Among the terms most understood by the respondents were the item KI3 (integrity is a 
combination of positive values and noble practices in life) that recorded the highest mean score $(\mathrm{m}=4.33$, $\mathrm{sp}=.570)$. This item was approved by $94.9 \%$ of respondents. No respondents disagree and only 8 respondents are not sure of this statement. The results of this study are in line with the terms put forth by PIN (2004) which define integrity as "the highest quality that exists in the whole and in the individual and organization based on ethics and ethical reflection. Ethical superiority means that ethical values are expressed by the individual. The results of this study are also in line with the study from Jamiah Manap et al. (2005), which defines integrity as an awareness, appreciation, and knowledge of pure values, including a full commitment to those values.

Whereas the less understood term was item KI6 (individuals with integrity were individuals of perfect behavior) scored lower than the other items with the score $(\mathrm{m}=4.09, \mathrm{sp}=.787)$. The results of this study showed that $3.8 \%$ of respondents disagreed with the integrity of the individual meaning perfect behavior. On the other hand, $13.4 \%$ of respondents were not sure of this statement. Based on previous studies, integrity has been described as a person with an awareness and appreciation of morals (Jamiah Manap et al. 2005).

Therefore, the researcher argues that integrity identifies the person with the best behavior. The results of this study show that respondents need to be exposed to the characteristics of people who deserve to be called in integrity are those who behave well. What is important is that perfect conditions do not mean that humans should not make mistakes in their lives, but that humans should minimize mistakes and mistakes. In this case (Ilhamie et al. 2013) it is argued that small and minor mistakes are made inadvertently such as complaining of having too much work, late attending meetings or late completing assigned tasks does not affect one's integrity, but this must be improved from time to time.

\section{Acknowledgment of Research Grant}

This article is part of a study under the research grant of Universiti Kebangsaan Malaysia PP 2019-015.

\section{References}

Al-Quran. Tafsir Pimpinan Ar-Rahman kepada Pengertian al-Quran. 2001. Cet. 12. Kuala Lumpur: JAKIM. Azizi Yahya. 2007. Menguasai Penyelidikan Dalam Pendidikan: Teori, Analisis Dan Interprestasi $\quad$ Data.

Kuala Lumpur: Pts Profesional Publishing Sdn. Bhd.

Azura Sahril. 2015. Syor Gubal Peruntukan Salah Laku Pejawat Awam. Sinar Online, 12 Februari 2015.

Bauman, D. C. 2013. Leadership And The Three Faces Of Integrity. The Leadership Quarterly, 24(3), 414-426. doi:10.1016/j.leaqua.2013.01.005.

Bryman, Alan \& Cramer, Duncan. 2005. Quantitative Data Analysis with SPSS 12 and 13: A Guide for Social Scientists. London: Routledge Taylor \& Francis Group.

Carter L. Stephen. 1996. Integrity. New York: HarperCollins.

Ilhaamie Abdul Ghani, Syarifah hayati Syed Ismail, Siti Arni Basir. 2013. Integriti menurut Islam dan Moden. Dlm. Kualiti Perkhidmatan Awam Di Malaysia Menurut Islam. Hlm 102-113. Kuala Lumpur: Penerbit Universiti Malaya.

Jamiah Manap et al. 2005. Pemantapan Nilai Integriti Individu Sebagai Teras Pembangunan Staf Berkualiti. Seminar Kebangsaan Sumber Manusia. Universiti Teknologi Malaysia, $2 \& 3$ Fabruari 2005, Johor Baru.

JIM, Jabatan Imigresen Malaysia (Atas Talian). Visi dan Misi. http://www.imi.gov.my/index.php/ms/profiljabatan/visi-dan-misi.html.[18Jun 2016].

JIM, Jabatan Imigresen Malaysia (Atas Talian). Pengenalan. http://www.imi.gov.my/index.php/ms/profiljabatan/pengenalan.html. [18 Jun 2016].

Kirk, R. E. 1984. Elementary Statistics, $2^{\text {nd }}$ ed. Englewood Cliffs: Prentice Hall.

Maisarah Rahim. 2016. Rasuah Dalam Kalangan Penjawat Awam:Di mana Silapnya. Utusan Online, 11 April 2016.

Merriam Webstre's collegiate Dictionary. 1996. Springfield: Meeriam-Webster Incorporated.

Munawar Ismail \& Nor Shahizan Ali.2012.Memahami Kuantitatif dan Kualitatif dalam Penyelidikan Pengajian Islam.Bangi:Penerbit FPI UKM.

Noraini Idris. 2010. Penyelidikan Dalam Pendidikan. Kuala Lumpur: Mc Graw Hill Education.

Palanski \& Yammarino. 2007. Integrity and Leadership: Clearing the Confusion. European Management Journal. Vol 21: 171-184.

Pelan Integriti Nasional (PIN). 2004. 